\title{
Role of Phosphorylation in Desensitization of Acetylcholine Receptors Expressed in Xenopus Oocytes
}

\author{
Peter W. Hoffman, ${ }^{a}$ Arippa Ravindran, ${ }^{b}$ and Richard L. Huganir \\ Department of Neuroscience, Howard Hughes Medical Institute, The Johns Hopkins University School of Medicine, \\ Baltimore, Maryland 21205
}

The nicotinic acetylcholine receptor $(\mathrm{AChR})$ is a pentameric complex made up of four types of subunits in the stoichiometry $\alpha_{2} \beta \gamma \delta$. These subunits have been shown to be differentially phosphorylated by cAMP-dependent protein kinase (PKA), protein kinase $C$, and a protein tyrosine kinase. $A$ variety of studies have suggested that phosphorylation of the AChR in vitro and in vivo regulates the rate of desensitization of the receptor. In this study we have used sitespecific mutagenesis and patch-clamp techniques to examine the role of phosphorylation in the regulation of desensitization of the AChR expressed in Xenopus oocytes. Expression of wild-type AChR in Xenopus oocytes results in the constitutive phosphorylation of the AChR on the $\gamma$ and $\delta$ subunits. This phosphorylation is apparently due to the high basal level of PKA in oocytes since a specific peptide inhibitor of PKA completely eliminated phosphorylation of the AChR by oocyte extracts in vitro. The phosphorylation of the AChR in oocytes was not significantly enhanced by forskolin or CAMP analogs or by coexpression with the catalytic subunit of PKA, suggesting that the basal activity of PKA in oocytes is sufficient to phosphorylate the receptor to a high stoichiometry. Using site-specific mutagenesis, the sites of phosphorylation were determined to be serines 353 and 354 on the $\gamma$ subunit and serines 361 and 362 on the $\delta$ subunit. To examine the functional properties of wild-type and mutant receptors lacking phosphorylation sites, we used patch-clamp techniques to measure the responses of outside-out patches to repetitive pulses of $\mathrm{ACh}$ using a rapid perfusion system. Wild-type and mutant receptors showed rapid concentration-dependent activation and desensitization to applied agonist. The time constant of desensitization of ensemble mean currents ranged from several hundred

\footnotetext{
Received Sept. 10, 1993; revised Dec. 15, 1993, accepted Dec. 31, 1993.

P.W.H. and A.R. contributed equally to this work. We are grateful to Craig Blackstone, Kathryn Wagner, Dr. Lin Mei, Dr. Sheridan Swope, Dr. Lynn Raymond, Dr. Gary Yellen, and Dr. Gordon Tomasselli for helpful discussion throughout this work. We also thank Carol Doherty, Lisa Moritz, Pablo Adler, and Alex Hoffman for technical assistance and Cindy Finch for preparation of the manuscript. This work was supported by The Council for Tobacco Rescarch-USA, Inc. (Grant 2735).

Correspondence should be addressed to Richard L. Huganir, Ph.D., Department of Neuroscience, Howard Hughes Medical Institute, The Johns Hopkins University School of Medicine, 725 North Wolfe Street, 900 Preclinical Teaching Building, Baltimore, MD 21205-2185.

a Molecular Neurobiology Unit, National Institutes on Aging, Baltimore, MD 21224.

bLaboratory of Molecular and Cellular Neurobiology, National Institute on Alcohol Abuse and Alcoholism, National Institutes of Health, Rockville, MD 20852.

Copyright (C) 1994 Society for Neuroscience $0270-6474 / 94 / 144185-11 \$ 05.00 / 0$
}

milliseconds at low ACh concentrations to $100-200$ msec at saturating concentrations. The desensitization time constants for mutant receptors lacking all phosphorylation sites were significantly slower than wild-type phosphorylated receptors at all concentrations of ACh tested. In addition, mutant receptors that had the serine residues changed to glutamate residues in order to mimic the negative charge of the phosphorylated serine residue produced receptors that had desensitization rates approaching those of the wild-type phosphorylated receptor. These results provide further support that phosphorylation of the nicotinic ACh receptor regulates its rate of desensitization.

IKey words: ion channel, protein kinases, cAMP, site-specific mutagenesis, desensitization, patch clamp, rapid perfusion]

The nicotinic acetylcholine receptor $(\mathrm{AChR})$ is the ligand-gated ion channel that mediates signal transduction at the postsynaptic membrane of the neuromuscular junction. The AChR has been extensively characterized and has served as a model system for the study of the structure, function, and regulation of neurotransmitter receptors and ion channels. The receptor is a pentameric complex made up of four types of subunits in the stoichiometry $\alpha_{2} \beta \gamma \delta$ (Galzi et al., 1991). In addition, the AChR is a phosphoprotein that has been shown to be phosphorylated and regulated by cAMP-dependent protein kinase (PKA), protein kinase $\mathrm{C}(\mathrm{PKC})$, and an endogenous protein tyrosine kinase in vitro and in vivo (Huganir and Greengard, 1987). Using purified preparations of PKA and $\mathrm{AChR}$, the sites phosphorylated by PKA were identified as serine 353 and serine 361 on the $\gamma$ and $\delta$ subunits, respectively (Yee and Huganir, 1987). These sites are in the large intraccllular loop that exists between the third and fourth membrane-spanning regions of each subunit.

Several functional effects have been reported for PKA phosphorylation of the AChR. Phosphorylation by PKA has been shown to increase the rate of rapid desensitization of purified and reconstituted $\mathrm{AChR}$ when quench-flow and stop-flow techniques were used to analyze $\mathrm{ACh}-$ dependent ion transport ( $\mathrm{Hu}-$ ganir et al., 1986). Treatment of muscle cells with the adenylyl cyclase activator forskolin, or with cAMP analogs, increased the phosphorylation and rate of desensitization of the AChR (Albuquerque et al., 1986; Middleton et al., 1986, 1988; Miles et al., 1987; Mulle et al., 1988). In primary cultures of mouse muscle cells, calcitonin gene-related peptide (CGRP) elevated the intracellular levels of cAMP and increased the phosphorylation and desensitization rate of the AChR (Mulle et al., i 988; Miles et al., 1989). However, in contrast, it has been reported 
that forskolin regulates desensitization of the AChR independently of protein phosphorylation (Wagoner and Pallotta, 1988; White, 1988), and that cAMP analogs (Wagoner and Pallotta, 1988; Cachelin and Colquhoun, 1989; Siara et al., 1990) and purified catalytic subunit (Wagoner and Pallotta, 1988; Siara et al., 1990) of cAMP-dependent protein kinase do not regulate the desensitization of the AChR. Phosphorylation by PKA has also been implicated in the regulation of subunit assembly of the AChR. Agents that raise intracellular levels of cAMP increase the number of cell surface Torpedo AChRs in mouse fibroblasts containing stably integrated Torpedo AChR subunits (Green et al., 1991 a; Ross et al., 1991). This effect has been attributed to an increase of PKA phosphorylation of unassembled $\gamma$ subunit (Green et al., $1991 \mathrm{~b}$ ).

To examine the role of phosphorylation in the regulation of the expression and desensitization of the nicotinic AChR, we have used the site-specific mutagenesis and patch-clamp techniques to analyze the function of wild-type and mutant receptors expressed in Xenopus oocytes. Mutant receptors lacking phosphorylation sites are expressed and assembled normally; however, the mutant receptors desensitize significantly slower than wild-type $\mathrm{AChR}$. In contrast, mutant receptors in which the serines were mutated to glutamate residues to mimic the phosphoserine residue had desensitization kinetics approaching that of the wild-type phosphorylated AChR.

\section{Materials and Methods}

Expression of $A C h R$. Adult female frogs (Xenopus laevis) were obtaincd from Xenopus I (Ann Arbor, MI) and kept in aquaria at $20^{\circ} \mathrm{C}$ under a $9 \mathrm{hr}$ light cycle. Pieces of ovary were surgically removed from frogs anesthetized in $0.1 \%$ Tricane (Sigma). Oocytes were isolated by incubation of the ovarian tissue with $1 \mathrm{mg} / \mathrm{ml}$ collagenase (type $1 \mathrm{~A}$, Sigma) in calcium-free OR2 medium (5 mM HEPES pH 7.6, $82.5 \mathrm{~mm} \mathrm{NaCl}$, $2.5 \mathrm{~mm} \mathrm{KCl}, 1 \mathrm{~mm} \mathrm{MgCl}_{2}$ ) for $2 \mathrm{hr}$ (Eppig and Steckmann, 1976). Healthy Dumont stage V-VI (Dumont, 1972) oocytes with a clear area indicating the position of the nucleus were then sorted out under a stereo microscope. RNA was transcribed from linearized plasmids containing the four subunits of the Torpedo californica AChR (gift of Gary Yellen) using the SP6 polymerase (Promega, Madison, WI). The RNA was resuspended in water, and approximately $50 \mathrm{ng}$ of an equimolar mixture of the $\alpha, \beta, \gamma$, and $\delta$ subunits was used for microinjections into oocytes to produce wild-type AChRs; mutant $\gamma$ and $\delta$ subunit RNA was used in place of the regular $\gamma$ and $\delta$ subunits to produce mutant AChRs. RNA mixtures were pressure injected using a positive displacement injector (Drummond Instruments, Broomhall, PA) through needles pulled from Drummond $10 \mu \mathrm{l}$ microdispenser capillary glass that was baked prior to pulling. The pipette tips were broken to $20-40 \mu \mathrm{m}$ diameter on a clean diamond knife with the aid of a Narishige micromanipulator. The injected oocytes were incubated at $20^{\circ} \mathrm{C}$ in amphibian saline, ND96 (5 mm HEPES pH 7.6, $96 \mathrm{~mm} \mathrm{NaCl}, 2 \mathrm{~mm} \mathrm{KCl}, 1.8 \mathrm{~mm} \mathrm{CaCl}_{2}, 1 \mathrm{~mm}$ $\mathrm{MgCl}_{2}$ ), supplemented with $100 \mathrm{U} / \mathrm{ml}$ penicillin and $100 \mu \mathrm{g} / \mathrm{ml}$ streptomycin sulfate (GIBCO-Bethesda Research Labs, Gaithersburg, MD), $0.5 \mathrm{~mm}$ theophylline, and $2 \mathrm{~mm}$ sodium pyruvate. The incubation media were changed daily. Biochemical and electrophysiological experiments were done between 2 and $5 \mathrm{~d}$ after RNA injection. Where indicated, media were supplemented with $20 \mu \mathrm{M}$ forskolin, 2 mM IBMX (3-isobutyl-1-methyl-xanthine), and $200 \mu \mathrm{M}$ 8-(-4-chlorophenylthio) cyclic adenosine $-3^{\prime}: 5^{\prime}$ monophosphate in experiments designed to increase PKA activity.

Site-specific mutagenesis. In vitro mutagenesis was performed using Bio-Rad Muta-Gene mutagenesis kit following the provided instructions (Kunkel et al., 1987). The oligonucleotides used for mutagenesis are as follows: $\gamma$ AA, 5'-CATAATCCCAAAGGCAGCTCTCCGTCTTGG-3'; $\gamma \mathrm{SA}, 5^{\prime}$-CATAATCCCAAAGGCACTTCTCCGTCTTGG-3'; $\gamma$ AS, $5^{\prime}$-CATAATCCCAAAGGAAGCTCTCCGTCTTGG-3'; $\delta$ AAA, 5'-GGAAATGTACCCAACAGCAGCGGCGCGTCGCAGCTTCAAA-3'; $\delta$ ASS, 5'-CCCAACAGAACTGGCGCGTCGCAGCTT-3'; $\delta$ SAS, 5'-GTACCCAACAGAAGCGCTGCGTCGCAG-3'; $\delta$ SSA, 5'-GGAAATGTACCCAACAGCACTGCTGCGTCGCAG-3'; $\delta$ AAS, $5^{\prime}$-GTAC-
CCAACAGAAGCGGCGCGTCGCAGCTT-3'; $\delta$ SAA, 5'-GGAAATGTACCCAACAGCAGCGCTGCGTCGCAGCT T-3'; $\delta$ ASA, 5'-GGAAATGTACCCAACAGCACTGGCGCGTCGCAGCTT-3'

For the charge mutants, mutagenesis was performed on the $\gamma \mathrm{AA}$ and $\delta$ AAA mutants and the oligonucleotides used were 5'-CCCAAAGGCATCTCTCCG-3' for the $\gamma$ charge mutant and 5'-CCCAACAGCATCGGCGCG-3' for the $\delta$ charge mutant.

Isolation of $A C h R$. To analyze expression and phosphorylation of AChRs, the oocytes (75-150 oocytes per lane) were incubated with either $0.1 \mathrm{mCi} / \mathrm{ml}{ }^{35} \mathrm{~S}$-labeled methionine (New England Nuclear; $>800 \mathrm{Ci} /$ $\mathrm{mmol}$ ) or $1 \mathrm{mCi} / \mathrm{ml}{ }^{32} \mathrm{P}$-labeled orthophosphoric acid (New England Nuclear; $8500 \mathrm{Ci} / \mathrm{mmol}$ ). Following incubation, the oocytes were resuspended in $1 \mathrm{ml}$ of buffer A [ $20 \mathrm{~mm}$ potassium phosphate buffer, $\mathrm{pH}$ 7.4, $150 \mathrm{~mm} \mathrm{NaCl}, 10 \mathrm{~mm}$ EDTA, $10 \mathrm{~mm}$ EGTA, $10 \mathrm{~mm}$ sodium pyrophosphate, $50 \mathrm{~mm} \mathrm{NaF}, 1 \mathrm{~mm} \mathrm{NaVO}$ (ortho), 10 mм iodoacetamide, $0.1 \mathrm{~mm}$ PMSF, $10 \mu \mathrm{g} / \mathrm{ml}$ pepstatin, $10 \mu \mathrm{g} / \mathrm{ml}$ chymostatin, $10 \mu \mathrm{g} /$ $\mathrm{ml}$ antipain, $10 \mu \mathrm{g} / \mathrm{ml}$ leupeptin, and $10 \mathrm{U} / \mathrm{ml}$ trasylol] and homogenized. Homogenates were centrifuged at $230,000 \times \mathrm{g}$ for $10 \mathrm{~min}$, the supernatants decanted, and the pellet resuspended in $1 \mathrm{ml}$ of buffer $\mathrm{A}$ plus $2.0 \%(\mathrm{w} / \mathrm{v})$ Triton $\mathrm{X}-100$ and $50 \mu \mathrm{g} / \mathrm{ml}$ RNase A. Following 20 min incubation on ice, the homogenate was again centrifuged at 230,000 $\times g$ for $10 \mathrm{~min}$ and the supernatant applied to $200 \mu \mathrm{l}$ of ACh affinity column (Huganir and Racker, 1982) and incubated for $1 \mathrm{hr}$ at $4^{\circ} \mathrm{C}$. AChR was eluted from the column with $75 \mathrm{~mm}$ carbachol and incubated for $1 \mathrm{hr}$ at $4^{\circ} \mathrm{C}$ with protein A Sepharose CL-4B (Pharmacia) coupled to a monoclonal antibody (mAb 88b), which recognizes the $\delta$ and $\gamma$ subunits of the AChR, through rabbit anti-mouse IgG (Cappel). The protein A Sepharose was washed with 20 volumes of buffer A plus $2 \%$ Triton X-100 and the bound AChRs eluted with SDS sample buffer ( 150 mм Tris- $\mathrm{HCl}$, pH 6.8, 2\% SDS, 5\% $\beta$-mercaptoethanol, 10\% glycerol, pyronin Y). This procedure resulted in approximately $50 \%$ recovery of the expressed AChR. Samples were applied directly to $8 \%$ SDS-PAGE (Laemmli, 1970), electrophoresed, stained, destained, and analyzed with autoradiography for ${ }^{32} \mathrm{P}$ or fluorography for ${ }^{35} \mathrm{~S} .{ }^{32} \mathrm{P}$ incorporation was usually in the $600 \mathrm{cpm}$ range in the $\gamma$ and $\delta$ subunit.

Electrophysiological recordings. Oocytes were prepared for electrophysiological recording as previously described (Methfessel et al., 1986). Briefly, the vitelline membrane was separated from the plasma membrane by exposing oocytes to hypertonic solution containing $220 \mathrm{~mm}$ $N$-methyl-D-glucamine, $220 \mathrm{~mm}$ aspartic acid, $2 \mathrm{~mm} \mathrm{MgCl}_{2}, 10 \mathrm{~mm}$ EGTA, and $10 \mathrm{~mm}$ HEPES (pH 7.2). The vitelline envelope was then completely removed with fine forceps. Stripped oocytes were transferred to amphibian saline for about 5 min prior to recording. Patch-clamp pipettes were fabricated from Corning \#7052 capillary glass $(1.6 \mathrm{~mm}$ o.d.; A-M Systems, Inc., Everett, WA) on a Sachs-Flamming micropipette puller model PC-84 (Sutter Instrument Co., San Rafael, CA). Pipettes were coated with Sylgard (Dow Corning, Midland, MI); their tips were heat polished using a homemade microforge and had DC resistances of 4-8 M . All patch-clamp recordings on oocytes were taken from excised outside-out patches, formed by standard techniques (Hamill et al., 1981). The patch pipette solution for all experiments contained $50 \mathrm{~mm} \mathrm{KF}, 27.5 \mathrm{~mm} \mathrm{KCl}, 1 \mathrm{~mm} \mathrm{MgCl}, 10 \mathrm{~mm}$ EGTA, $8.8 \mathrm{~mm}$ sorbitol, $1 \mathrm{~mm}$ sodium vanadate, and $20 \mathrm{~mm}$ potassium phosphate buffer $(\mathrm{pH}$ 7.6). The extracellular solution contained $97.5 \mathrm{~mm} \mathrm{KCl,} 4 \mathrm{~mm}$ HEPES (pH 7.6 with $\mathrm{KOH}$ ), $1 \mathrm{mM} \mathrm{MgCl}_{2}, 0.2 \mathrm{~mm}$ EGTA, and $8.8 \mathrm{~mm}$ sorbitol. Patches were continuously perfused, and currents were elicited by application of the bath solution containing the desired concentration of acetylcholine (ACh). An outside-out patch was positioned in a customdesigned bath at the convergence point of streams of control and $\mathrm{ACh}$ containing solution. Switching between streams of solution was performed by two miniature solenoid three-way isolation valves (Neptune Research, Inc., Maplewood, NJ), which were controlled by a personal computer. The speed of solution changes was routinely tested by monitoring the open tip current caused by differences in liquid junction potentials when switching between an external solution containing 150 $\mathrm{mm} \mathrm{NaCl}$ to one with $150 \mathrm{~mm} \mathrm{KCl}$. Solution exchange times of 1-2 msec were routinely achieved with this system. This method of rapid perfusion is a minor modification of the method explained elsewhere (Maconochie and Knight, 1989). ACh was applied to the patch in 3-5 sec pulses at 30-60 sec intervals. Currents were measured using Axopatch-1C patch-clamp amplifier and digitized by TL1 DMA interface (Axon Instruments, Inc., Foster City, CA).

Data acquisition and analysis were performed with a personal computer, using pClaMP (5.5.1) software (Axon Instruments, Inc., Foster City, CA). ACh-induced current records were filtered at $0.25 \mathrm{kHz}(-3$ 

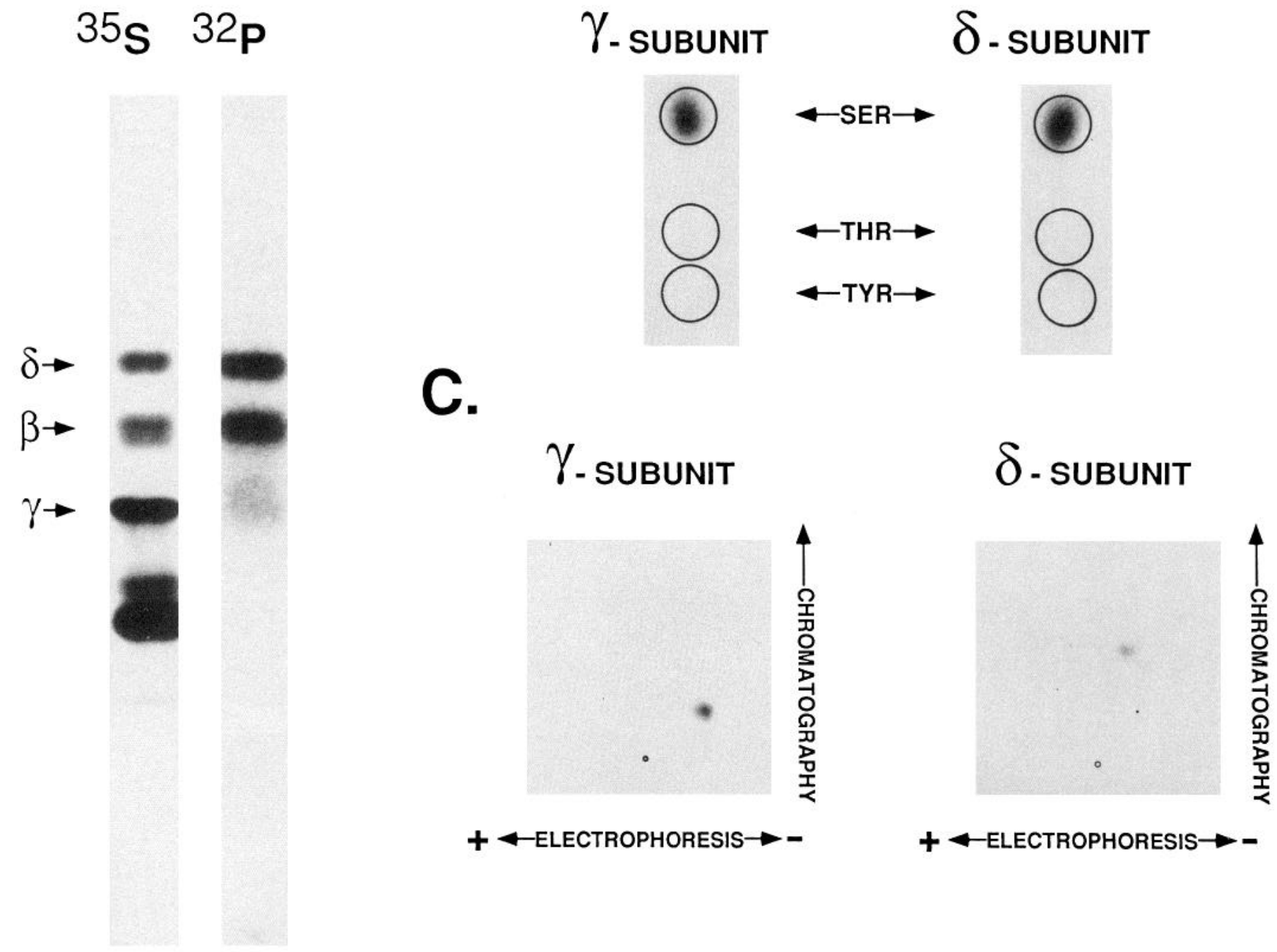

Figure 1. Expression and phosphorylation of wild-type AChR in Xenopus oocytes. A, Isolation of ${ }^{35} \mathrm{~S}-$ and ${ }^{32} \mathrm{P}-\mathrm{labeled} \mathrm{AChR}$ from Xenopus oocytes. RNAs encoding the wild-type AChR subunits from Torpedo were injected into Xenopus oocytes and allowed to express in media containing either ${ }^{35} \mathrm{~S}$-labeled methionine $\left({ }^{35} S\right)$ or ${ }^{32} \mathrm{P}$-labeled orthophosphoric acid $\left({ }^{32} P\right)$. AChRs were then isolated as described in Materials and Methods, electrophoresed on SDS-PAGE gels, and visualized by autoradiography. B. Phosphoamino acid analysis of $\gamma$ and $\delta$ subunits expressed in Xenopus oocytes. AChRs were expressed and labeled with ${ }^{32} \mathrm{P}$-phosphate in oocytes as described in Materials and Methods. Phosphorylated subunits were excised from the gel, acid hydrolyzed, and subjected to one-dimensional thin-layer electrophoresis. Circles indicate the position of internal standards, phosphoserine $(S E R)$, phosphothreonine $(T H R)$, and phosphotyrosine $(T Y R)$. C. Two-dimensional phosphopeptide maps of $\gamma$ and $\delta$ subunits expressed in Xenopus oocytes. AChRs were expressed and ${ }^{32} \mathrm{P}$-labeled as described in Materials and Methods. The $\gamma$ and $\delta$ subunits were excised from gels and digested with thermolysin. The resulting phosphopeptides were applied to thin-layer chromatography plates and separated by electrophoresis and ascending chromatography. Origin is circled.

$\mathrm{dB}$ frequency) with an 8-pole low-pass Bessel filter, digitized at $0.5-1$ $\mathrm{kHz}$, and stored on the computer disk. Macroscopic current traces from 3-14 individual episodes were combined to form ensemble averages to measure the peak current and the rate of desensitization. The decay phase of desensitization was normally fit to a single exponential by a least-square fitting routine using the CLAMPFIT routine of pCLAMP. All values are presented as mean $\pm \mathrm{SD}$. Differences in mean desensitization time constants between the various groups were assessed using twotailed Student's unpaired $t$ test using STATVIEw (Abacus Concepts, Berkeley, CA). The level of statistical significance was set at $p<0.05$.

Phosphoamino acid analysis and peptide maps. Two-dimensional thermolytic phosphopeptide mapping of excised gel pieces was performed as described by Huganir and Greengard (1983). Phosphoamino acid analysis was as described by Miles et al. (1989).

PKA assay. Oocytes were prepared as described above and incubated for $2 \mathrm{~d}$ in ND96. Fifty oocytes were resuspended in $1 \mathrm{ml}$ buffer A plus
$2 \%$ Triton X-100 and homogenized. Varying amounts of the whole-cell extract $(5-20 \mu \mathrm{l})$ were incubated at $30^{\circ} \mathrm{C}$ in a buffer containing $40 \mathrm{~mm}$ HEPES pH 7.0, $20 \mathrm{~mm} \mathrm{MgCl}_{2}$, and $10 \mu \mathrm{M}{ }^{32} \mathrm{P}-\mathrm{ATP}(1000 \mathrm{cpm} / \mathrm{pmol})$, using $10 \mu \mathrm{M}$ Kemptide as a PKA-specific peptide substrate (Kemp, 1976). Where noted, some assays also contained $10 \mu \mathrm{M} \mathrm{IP} 20$-amide, a specific peptide inhibitor of PKA (Cheng et al., 1986), or $10 \mu \mathrm{M}$ cAMP. The assay was stopped by the addition of $1 / 10 \mathrm{vol}$ of $0.5 \mathrm{~mm}$ EDTA, $\mathrm{pH}$ 8.0. PKA activity was calculated as the amount of ${ }^{32} \mathrm{P}$ incorporated into Kemptide that was inhibitable by $\mathrm{IP}_{20}$-amide. Protein concentration was determined using the Pierce Coomassie Assay Reagent using BSA as the standard.

Phosphorylation of purified AchR. Whole-cell oocyte extract was prepared as described above and aliquots $(0.25 \mathrm{mg}$ protein) were incubated at $30^{\circ} \mathrm{C}$ in $0.1 \mathrm{ml}$ of the PKA assay buffer described above with $0.1 \mathrm{mg} /$ ml purified Torpedo AChR (Huganir and Racker, 1982) added as a substrate. Indicated reactions contained $10 \mu \mathrm{M} \mathrm{IP}{ }_{20}$-amide (Cheng et al., 


\section{$\delta$ subunit}

\begin{tabular}{c|c|l} 
LANE & NAME & \multicolumn{2}{c}{ SEQUENCE } \\
\hline 1 & WT & ARG ARG SER SER SER VAL \\
\hline 2 & AAA & ARG ARG ALA ALA ALA VAL \\
\hline 3 & ASS & ARG ARG ALA SER SER VAL \\
\hline 4 & SAS & ARG ARG SER ALA SER VAL \\
\hline 5 & SSA & ARG ARG SER SER ALA VAL \\
\hline 6 & AAS & ARG ARG ALA ALA SER VAL \\
\hline 7 & SAA & ARG ARG SER ALA ALA VAL \\
\hline 8 & ASA & ARG ARG ALA SER ALA VAL \\
\hline
\end{tabular}

Figure 2. Mutagenesis mapping of phosphorylation sites of the Torpedo AChR expressed in oocytes. For each subunit tested the indicated mutant subunit was coexpressed with wild-type subunits, labeled with ${ }^{32} \mathrm{P}$-phosphate, and isolated as described in Materials and Methods. For each lane, the mutant name and corresponding amino acid sequence at the PKA phosphorylation site are indicated at the top. The purified AChRs were run on SDS-PAGE gels, dried, and subjected to autoradiography.
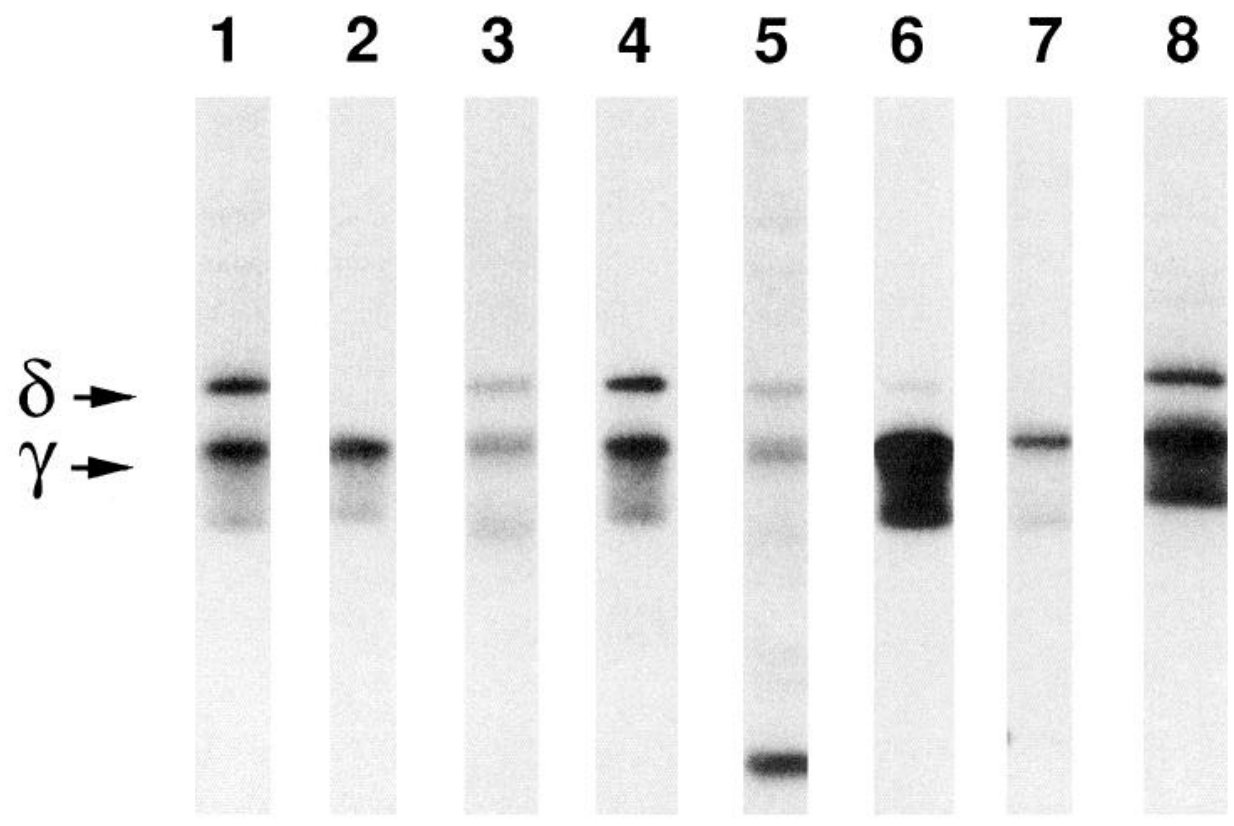

1986) or $10 \mu \mathrm{M}$ cAMP. The reaction was stopped by the addition of $1 / 10 \mathrm{vol}$ of $0.5 \mathrm{~mm}$ EDTA, $\mathrm{pH} 8.0$, brought to $1 \mathrm{ml}$ by the addition of buffer A plus $2 \%$ Triton X-100 and applied directly to $100 \mu \mathrm{l}$ of protein A Sepharose CL-4B coupled to mAb 88b (see above). Following $1 \mathrm{hr}$ incubation at $4^{\circ} \mathrm{C}$, the column was washed with 40 column volumes of buffer A plus $2 \%$ Triton X-100 and AChRs eluted and analyzed as described above.

Surface $\alpha$-bungarotoxin binding assay. Oocytes were prepared as described above, injected with mRNA encoding the Torpedo AChR wildtype or mutant subunits, and allowed to incubate 2.d in ND96. Oocytes were then resuspended in groups of three in ND96 plus 1\% BSA and $2.5 \mathrm{nM}^{125} \mathrm{I}-\alpha$-bungarotoxin (Amersham; $1900 \mathrm{Ci} / \mathrm{mmol}$ ), and incubated

with gentle rocking at room temperature for $2 \mathrm{hr}$. They were then washed with several changes of ND96 plus $1 \%$ BSA. ${ }^{125}$ I- $\alpha$-bungarotoxin binding was assayed in a gamma counter. Nonspecific background was determined by assaying uninjected oocytes. Surface expression of the AChR was $1-3 \mathrm{fmol} /$ oocyte for both wild-type and mutant receptors.

\section{Results}

Phosphorylation of AChR expressed in Xenopus oocytes

To investigate the state of phosphorylation of the AChR expressed in Xenopus oocytes, the mRNAs for all four wild-type 


\section{$\gamma$ subunit}

\begin{tabular}{c|c|c} 
LANE & NAME & \multicolumn{2}{c}{ SEQUENCE } \\
\hline 1 & WT & ARG ARG ARG SER SER PHE \\
\hline 2 & AA & ARG ARG ARG ALA ALA PHE \\
\hline 3 & SA & ARG ARG ARG SER ALA PHE \\
\hline 4 & AS & ARG ARG ARG ALA SER PHE \\
\hline
\end{tabular}

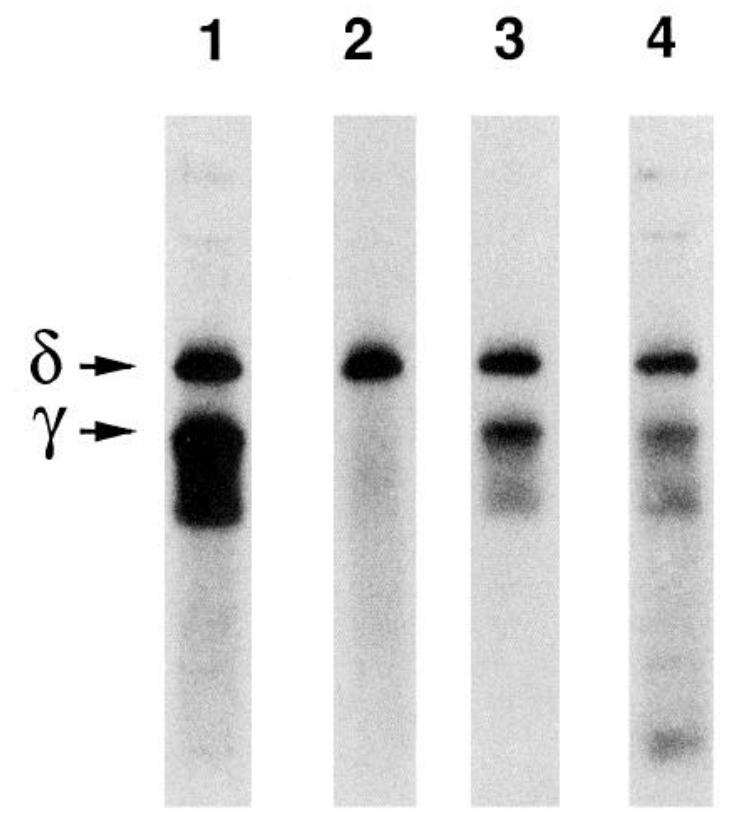

Figure 2. Continued.

receptor subunits were injected into oocytes and incubated in media containing either ${ }^{35} \mathrm{~S}$-methionine or ${ }^{32} \mathrm{P}$-orthophosphoric acid. Following $2 \mathrm{~d}$ incubation, nicotinic receptors were isolated with a double affinity column method consisting of an $\mathrm{ACh}$ affinity column (Huganir and Racker, 1982) followed by an immunoaffinity column consisting of a monoclonal antibody against AChR (mAb 88b) coupled to protein A Sepharose. The $\mathrm{AChR}$ isolated from oocytes labeled with ${ }^{35} \mathrm{~S}$-methionine consists of four major proteins with apparent molecular weights of $40 \mathrm{kDa}, 50 \mathrm{kDa}, 60 \mathrm{kDa}$, and $65 \mathrm{kDa}$ that comigrate with the $\alpha, \beta, \gamma$, and $\delta$ subunits, respectively, of the purified Torpedo AChR (Fig. 1A). Preincubation of the membrane extract with $\alpha$-bungarotoxin, which inhibits binding of the receptor to the $\mathrm{ACh}$ column, blocked the isolation of all protein species (data not shown), confirming the specificity of the isolation procedure. In contrast, when the AChR is isolated from oocytes incubated in ${ }^{32} \mathrm{P}$-phosphate, only the $\gamma$ and $\delta$ subunits are labeled (Fig. $1 A$ ). The broad band running below the $\gamma$ subunit is a proteolytic product of the $\gamma$ subunit (note absence of the band in Fig. 2, $\gamma$ AA mutant). The isolation of these ${ }^{32} \mathrm{P}$-labeled proteins was also blocked by preincubation of the membrane extract with $\alpha$-bungarotoxin (data not shown). This pattern of phosphorylation is consistent with phosphorylation of the $\mathrm{AChR}$ on sites previously identified as those phosphorylated by PKA (Huganir and Greengard, 1983).

To investigate further the phosphorylation of the AChR, the ${ }^{32} \mathrm{P}$-labeled $\gamma$ and $\delta$ subunits were excised from gels and subjected to phosphoamino acid analysis and two-dimensional phosphopeptide mapping. Phosphoamino acid analysis showed that both the $\gamma$ and $\delta$ subunits are phosphorylated solely on serine residues (Fig. $1 B$ ). The phosphopeptide maps demonstrate that each subunit contains a single thermolytic phosphopeptide (Fig. 1C). The migration of these peptides was similar to thermolytic phosphopeptides from the $\gamma$ and $\delta$ subunits of the purified Torpedo AChR phosphorylated in vitro with purified PKA (Yee and Huganir, 1987).

\section{Mutagenesis mapping of phosphorylation sites}

In order to precisely map the phosphorylation sites on the $\gamma$ and $\delta$ subunits, we began with the assumption that the sites were those known to be phosphorylated by PKA. This is consistent with the experiments presented above and with the fact that Xenopus oocytes are known to have high basal levels of PKA activity (Maller and Krebs, 1977; Huchon et al., 1981; Cicirelli et al., 1988). The PKA sites on $\gamma$ and $\delta$ subunits contain multiple contiguous serines that could potentially be phosphorylated. The amino acid sequence at the PKA site on the $\gamma$ subunit is RRRSSF (amino acids 350-355) and the amino acid sequence at the PKA site on the $\delta$ subunit is RRSSSV (amino acids 358363). To test whether these sites were phosphorylated in oocytes, we created mutations that replaced all the serine residues at each site with alanine residues. These mutants were expressed in oocytes in the presence of ${ }^{32} \mathrm{P}$-phosphate and the AChRs isolated. Mutagenesis of all the serine residues within the PKA consensus site in either the $\gamma$ or $\delta$ subunit eliminated the observed phosphorylation of the subunits, confirming that these serines are the sites of phosphorylation (Fig. 2, $\gamma$ subunit AA mutant and $\delta$ subunit AAA mutant). In each case the other subunits expressed were wild type, allowing the $\delta$ subunit in the $\gamma$ subunit mutagenesis experiments and the $\gamma$ subunit in the $\delta$ subunit mutagenesis experiments to act as positive controls. When mRNAs encoding the $\gamma$ subunit AA mutant and the $\delta$ subunit AAA mutant were coinjected with wild-type $\alpha$ and $\beta$ mRNAs, AChRs were produced that were found to assemble normally on the cell surface as judged by assaying surface $\alpha$-bungarotoxin binding (data not shown) and by analyzing $\mathrm{ACh}$-induced currents using patch-clamp recording techniques (see Table 2, Figs. 5-7). No consistent differences in the level of expression of $\alpha$-bungarotoxin binding or peak $\mathrm{ACh}$-induced conductance were observed between wild-type receptors and receptors containing mutant $\gamma$ and $\delta$ subunits.

To analyze the sites of phosphorylation in more detail, we created a set of mutants with all possible combinations of serine to alanine mutations at the PKA sites for each subunit (Fig. 2). The results for the $\gamma$ subunit show that both serine residues (serines 353 and 354) at this site can be phosphorylated. The SA mutant appears to be more highly phosphorylated than the AS mutant (compare the intensity of each $\gamma$ subunit to the corresponding $\delta$ subunit). Analysis of the $\delta$ mutants showed that all mutants that encode a single serine and two alanines on the $\delta$ subunit are phosphorylated to some extent except the SAA 
Table 1. Assay of PKA activity in oocyte extracts

\begin{tabular}{lcc} 
& Basal & +cAMP \\
\hline Naive & $5.5 \pm 1.1$ & $5.3 \pm 1.2$ \\
C $\alpha$ injected & $986 \pm 232$ & $959 \pm 118$
\end{tabular}

Extracts were produced and assayed as described in Materials and Methods from equal numbers of uninjected oocytes (naive) or oocytes injected with mRNA from the $\mathrm{C} \alpha$ cDNA, encoding the catalytic subunit of PKA ( $\mathrm{C} \alpha$ injected). PKA activity is expressed as $\mathrm{pmol} / \mathrm{min} / \mathrm{mg} \pm \operatorname{SE}(n=3)$.

mutant (Fig. 2, $\delta$ lane 7). The ASA mutant (Fig. 2, $\delta$ lane 8 ) was a good substrate, while the AAS mutant (Fig. 2, $\delta$ lane 6) appears to be a poor substrate but is phosphorylated. Thus, the second and third serines (serines 361 and 362) were capable of being phosphorylated while the first serine (serine 360 ) does not appear to be used as a phosphorylation site.

\section{AChR is highly phosphorylated}

To examine whether the phosphorylation of the AChR expressed in oocytes can be modulated, oocytes were incubated with agents that increase intracellular cAMP levels. Phosphorylation of the AChR was not significantly nor consistently increased by incubation in forskolin, an activator of adenylate cyclase, a cAMP analog [8-(-4-chlorophenylthio) cyclic adenosine- $3^{\prime}: 5^{\prime}$ monophosphate], and IBMX (Fig. $3 ; n=4$ ). In addition, coexpression of the catalytic subunit of PKA $(\mathrm{C} \alpha)$ in the oocytes also had little or no consistent effect on the level of phosphorylation of the $\gamma$ and $\delta$ subunits (Fig. $3 ; n=2$ ). In order to test the level of PKA activity in naive oocytes and oocytes injected with $\mathrm{C} \alpha$ mRNA, PKA activity of whole-cell oocyte extracts was assayed with the synthetic peptide substrate Kemptide in the presence and absence of cAMP. The addition of cAMP to the assay buffer did not cause an increase in PKA activity, suggesting that most of the PKA in the extract was in the active form (Table 1). Moreover, the injection of the $\mathrm{C} \alpha$ mRNA increased the level of PKA activity approximately 180 fold over the naive extract (Table 1). Taken together, these results suggest that the basal level of PKA activity in oocytes is sufficient to highly phosphorylate the AChR.

\section{AchR is phosphorylated by PKA in oocytes}

To test whether all the observed phosphorylation was due to PKA activity, a whole-cell oocyte extract was used to phosphorylate purified Torpedo AChR in vitro. As shown in Figure 4, the extract phosphorylated purified AChR on the $\gamma$ and $\delta$ subunits. This phosphorylation was completely inhibited by the addition to the reaction of $\mathrm{IP}_{20}$-amide (Cheng et al., 1986), a specific peptide inhibitor of PKA, demonstrating that all the observed phosphorylation was due to PKA activity. The addition of CAMP to the reaction mixture did not cause a significant increase in AChR phosphorylation (Fig. 4). To control for any possible effects of Triton solubilization on PKA, such as detergent-mediated disassociation of the regulatory subunit, a similar experiment was performed using a whole-cell homogenate. The results were the same as above (data not shown), demonstrating that Triton solubilization did not artificially stimulate PKA activity.

\section{Electrophysiological characterization of wild-type and mutant AChRs}

To analyze the functional properties of wild-type and mutant AChRs, 3-5 sec pulses of ACh were repetitively applied to out-

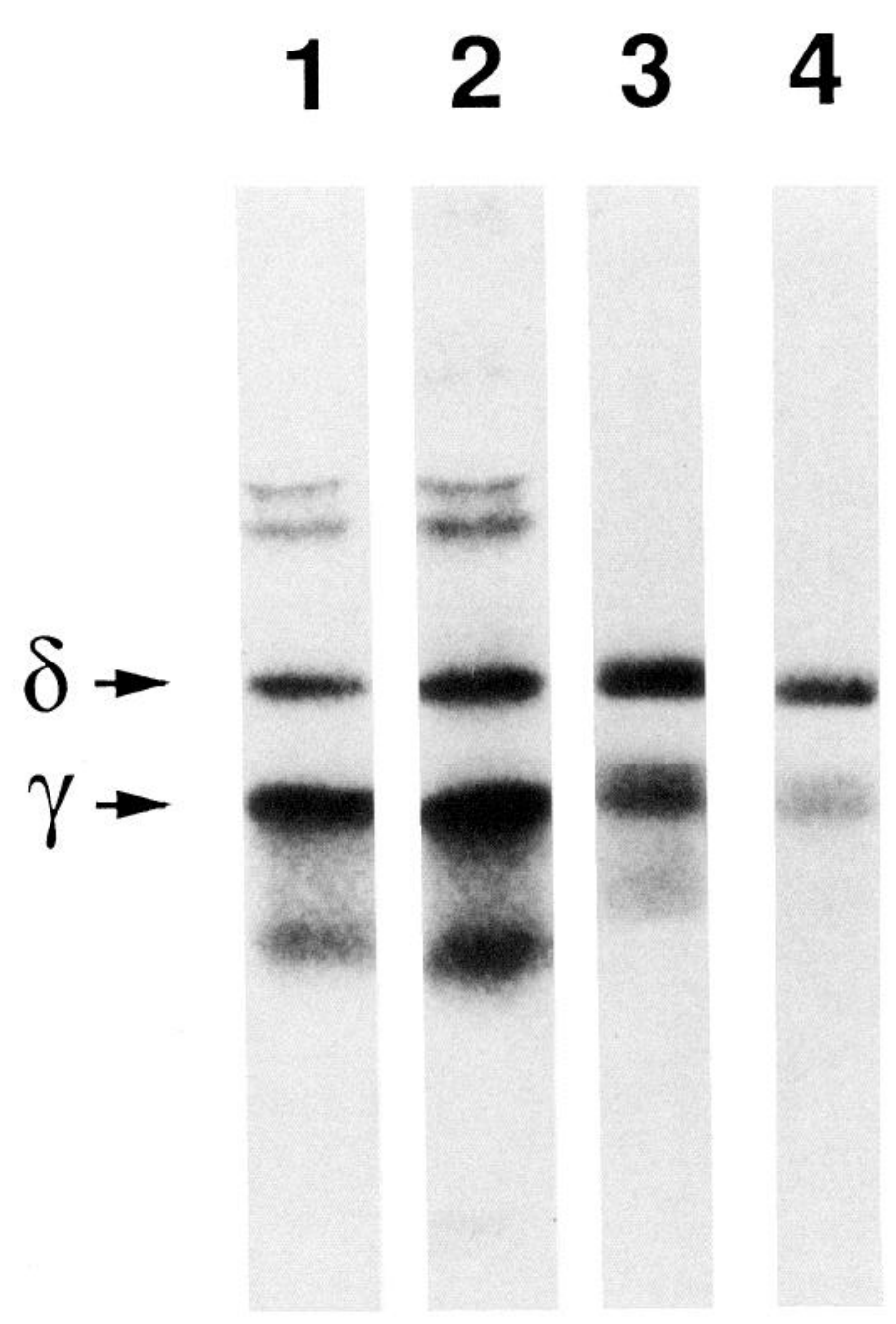

Figure 3. Lack of modulation of AChR phosphorylation by PKA activators and overexpression of PKA. Equal numbers of oocytes were injected with mRNA for wild-type AChR subunits and incubated in media containing ${ }^{32} \mathrm{P}$-orthophosphate acid. AChRs were isolated as described in Materials and Methods, separated on SDS-PAGE gels, and subjected to autoradiography. Lane 1, oocytes injected with mRNA wild-type AChR subunits; lane 2, same number and batch of oocytes as in lane 1 injected with wild-type AChR subunits and incubated in media supplemented with $20 \mu \mathrm{M}$ forskolin, $2 \mathrm{mM}$ IBMX, and $200 \mu \mathrm{M}$ 8-(-4-chlorophenylthio) cyclic adenosine- $3^{\prime}: 5^{\prime}$-monophosphate; lane 3 , oocytes injected with mRNA for wild-type AChR subunits alone; lane 4 , same number and batch of oocytes as in lane 3 injected with mRNA for wild-type AChR subunits plus the catalytic subunit of PKA.

side-out patches using a rapid perfusion system. Superfusion of the patches with rapidly rising pulses of ACh resulted in "macroscopic" inward currents that were activated within $6 \mathrm{msec}$ (see Fig. 5). This activation time primarily reflects the time course of the perfusion system and the time needed for ACh binding and channel opening. Activation of the channels is followed by a slower decay of current due to desensitization with decay time constants ranging from 100 to $200 \mathrm{msec}$ at saturating $\mathrm{ACh}$ concentration. Shown in Figure 5 are examples of ensemble mean currents obtained from patches containing wild-type and mutant AChRs exposed to the rapid application of different concentrations of ACh. Although the peak response varied from patch to patch due to the variability of expression of the AChR, within a patch the peak response increased on raising $\mathrm{ACh}$ con- 
centration from 10 to $100 \mu \mathrm{M}$. The peak current in a typical patch at $100 \mu \mathrm{M}$ ACh was several hundred picoamperes while at $10 \mu \mathrm{M}$, the peak amplitude of the ensemble mean current was less than $100 \mathrm{pA}$. In addition, the time course of desensitization was clearly dose dependent (Figs. 5, 6; Table 2). At $100 \mu \mathrm{M} \mathrm{ACh}$ there was rapid activation of channels followed by rapid desensitization, whereas at $10 \mu \mathrm{M} \mathrm{ACh}$ the channels activated rapidly, however, the rate of desensitization was slow (Table 2). In most cases, the time course of desensitization of wild-type and mutant receptors could be fitted with a single exponential function, though in some patches the rate of desensitization was biphasic and was best described by the sum of two exponential functions. In addition, the desensitization rates of the AChRs were found to be variable from patch to patch (Fig. 6, Table 2), as has been reported previously (Dilger and Bret, 1990; Franke et al., 1991; Dilger and Liu, 1992; Bufler et al., 1993). This variation may be due to posttranslational modification of the receptor channel or it may be due to a modal shift in AChR channel gating, as suggested by Naranjo and Brehm (1993).

In order to examine the effects of phosphorylation on $\mathrm{AChR}$ desensitization, the rates of desensitization of wild-type receptors (Fig. $5 A, D, G, J$ ) were compared with those of "point-mutant" receptors (Fig. $5 B, E, H, K$ ) lacking all phosphorylation sites (using the AA $\gamma$ subunit mutant and the AAA $\delta$ subunit mutant). In spite of the large variation in desensitization rates, significant differences between wild-type and mutant receptors were observed (Fig. 6, Table 2). The desensitization rates of "pointmutant" receptors lacking all of the phosphorylation sites were significantly slower at all ACh concentrations tested ( $p \leq 0.0005)$. Moreover, mutation of serine 353 on the $\gamma$ subunit and serine 361 on the $\delta$ subunit to glutamate residues in order to mimic the negative charge of the phosphate produced a mutant receptor ("charge mutant") that desensitized with a rate approaching the wild-type phosphorylated receptor at all concentrations of $\mathrm{ACh}$ tested, although the data was not statistically significant at all ACh concentrations (Figs. 5C,F,I; 6; Table 2). Figure 7 illustrates the steady state desensitization of the three types of receptors. Though the steady state level of channel opening decreased in a concentration-dependent manner, there was no significant difference between the wild-type and mutant receptors. In preliminary experiments we compared the single-channel conductance of wild-type and point-mutant receptors. There

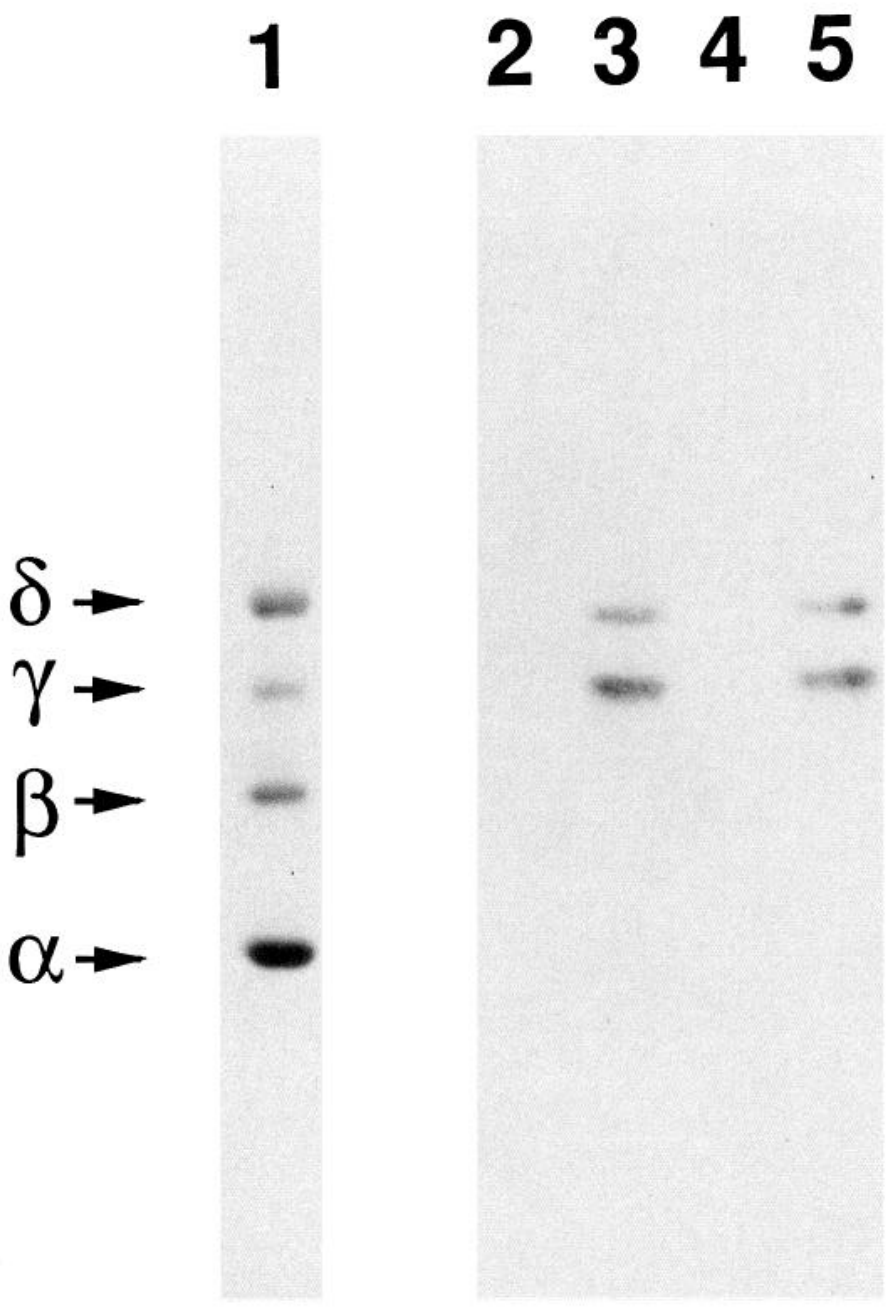

Figure 4. Phosphorylation of purified AChR by an oocyte extract. Purified AChR $(10 \mu \mathrm{g})$ was phosphorylated by an oocyte extract as described in Materials and Methods, isolated by an immunoaffinity column, separated on SDS-PAGE gels, and subjected to autoradiography. Lane 1, protein stain of $10 \mu \mathrm{g}$ pure AChR separated on an SDSPAGE gel; lane 2, control incubation without added AChR; lane 3, AChR phosphorylation by oocyte extract; lane 4, AChR incubated with oocyte extract plus $\mathrm{IP}_{20}$-amide; lane $5, \mathrm{AChR}$ incubated with oocyte extract plus cAMP.

Table 2. Properties of the wild-type and mutant receptors

\begin{tabular}{lllccc} 
& $\begin{array}{l}\mathrm{ACh} \\
(\mathrm{mM})\end{array}$ & $\begin{array}{l}\tau \pm \mathrm{SD} \\
(\mathrm{msec})\end{array}$ & $\begin{array}{l}I_{p} \pm \mathrm{SD} \\
(\mathrm{pA})\end{array}$ & $\begin{array}{l}I_{\text {ss }} \pm \mathrm{SD} \\
\left(\% \text { of } I_{p}\right)\end{array}$ & $\begin{array}{l}\text { \# } \\
\text { Patches }\end{array}$ \\
\hline Wild type & 0.1 & $211 \pm 63$ & $200 \pm 242$ & $11 \pm 6$ & 65 \\
& 0.05 & $265 \pm 92$ & $96 \pm 66$ & $16 \pm 9$ & 42 \\
& 0.025 & $497 \pm 123$ & $140 \pm 109$ & $22 \pm 11$ & 35 \\
Point mutant & 0.01 & $505 \pm 146$ & $178 \pm 75$ & $38 \pm 11$ & 6 \\
& 0.1 & $364 \pm 165$ & $629 \pm 539$ & $10 \pm 4$ & 65 \\
& 0.05 & $430 \pm 100$ & $313 \pm 233$ & $9 \pm 6$ & 23 \\
& 0.025 & $743 \pm 220$ & $151 \pm 158$ & $33 \pm 13$ & 56 \\
Charge mutant & 0.01 & $899 \pm 306$ & $88 \pm 23$ & $37 \pm 6$ & 13 \\
& 0.1 & $297 \pm 61$ & $89 \pm 46$ & $10 \pm 4$ & 8 \\
& 0.05 & $347 \pm 55$ & $176 \pm 114$ & $8 \pm 6$ & 6 \\
& 0.025 & $607 \pm 137$ & $80 \pm 39$ & $16 \pm 4$ & 14
\end{tabular}

Data are average values of desensitization time constants $(\tau)$, peak amplitudes $\left(I_{p}\right)$, and steady state currents $\left(I_{\mathrm{ss}}\right)$ at various $\mathrm{ACh}$ concentrations for wild-type, point-mutant, and charge-mutant receptors. 


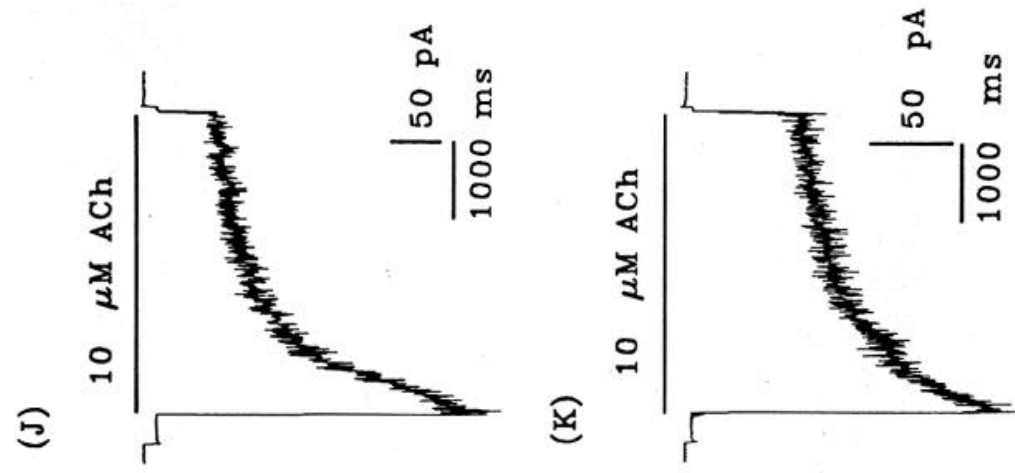

폻ำ

要这

헝 站

떠승

जी

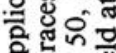

व.

동

$0<4$

马

政安。

क्ष

踏

荡可

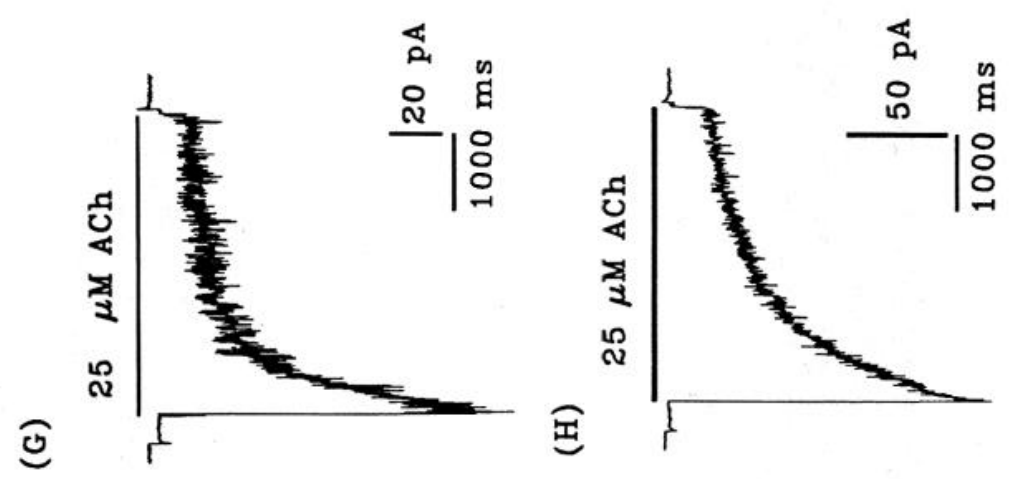

$\Xi$

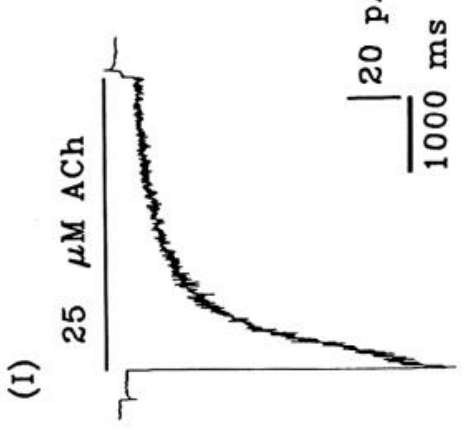

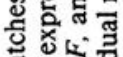

a

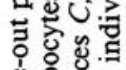

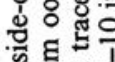

諟我

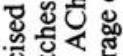

政

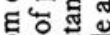

옹

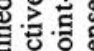

路

年

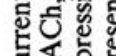

a
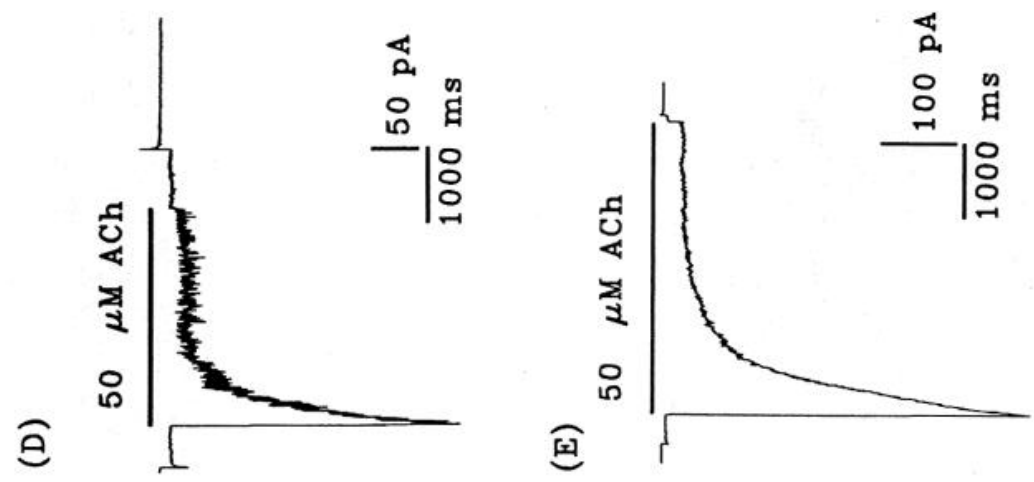

臣

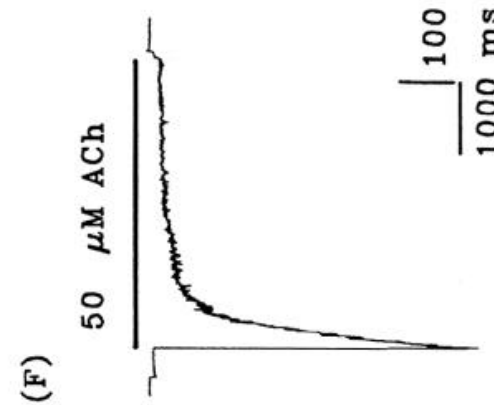

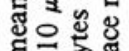

마웜

हี

这

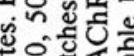

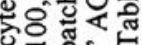

언ㅎㅇ 픔ㅍ

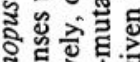

\% $\geq 5$ क

边㐘

은 可唍

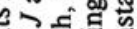

驱实
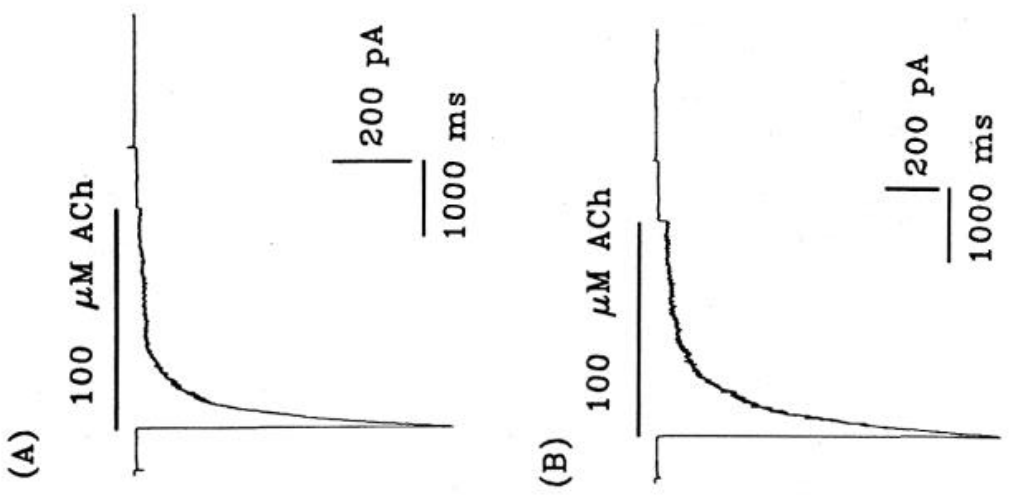

ठิ๋ ₹

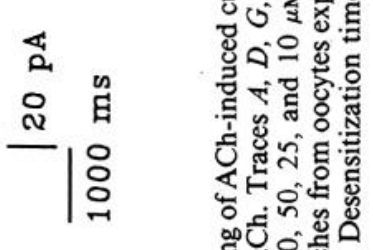

데 ๘

눈응

엉옹ㅎㅇ

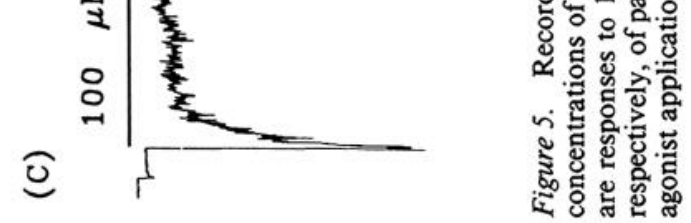




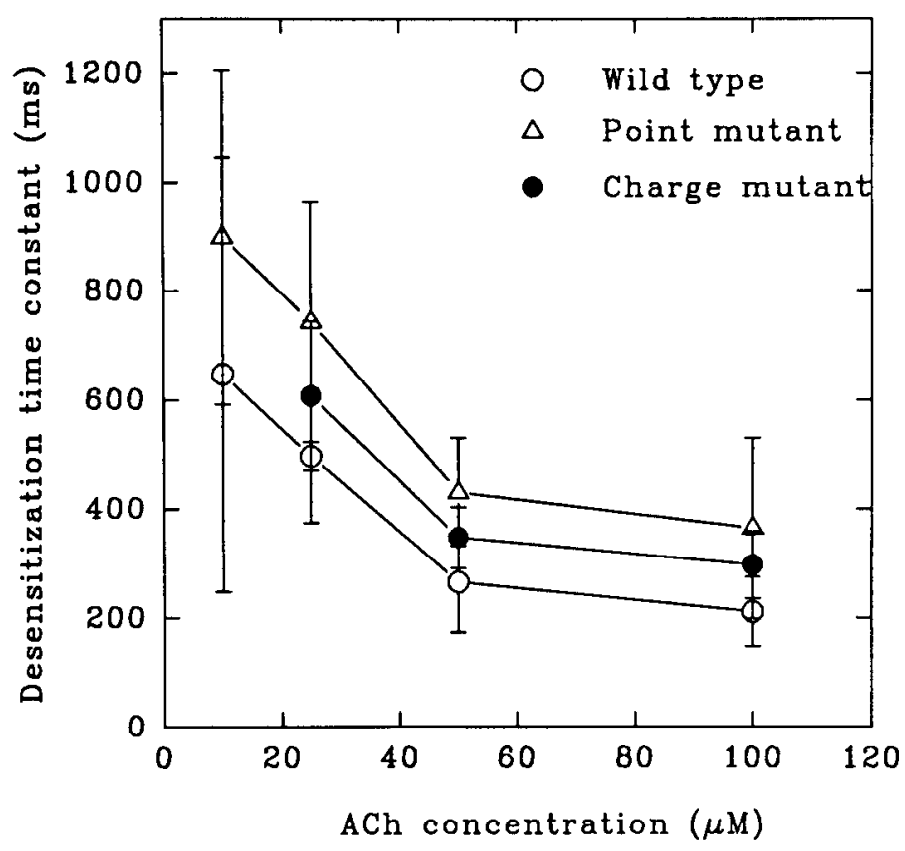

Figure 6. ACh concentration dependence of desensitization. Time constant of desensitization versus $\mathrm{ACh}$ concentration for wild type, charge mutant, and point mutant. Values are mean \pm SD. Patches were held at $-70 \mathrm{mV}$. The statistical differences between the mean desensitization time constants among the various groups were determined using the two-tailed Student's unpaired $t$ test; the significance values were as follows: $\mathrm{ACh}=100 \mu \mathrm{M}$, point mutant versus wild type, $p<$ $0.0005 ; \mathrm{ACh}=100 \mu \mathrm{M}$, charge mutant versus wild type, $p<0.05 ; \mathrm{ACh}$ $=100 \mu \mathrm{M}$, point mutant versus charge mutant, $p<0.375 ; \mathrm{ACh}=50$ $\mu \mathrm{M}$, point mutant versus wild type, $p<0.0005 ; \mathrm{ACh}=50 \mu \mathrm{M}$, charge mutant versus wild type, $p<0.025 ; \mathrm{ACh}=50 \mu \mathrm{M}$, point mutant versus charge mutant, $p<0.1 ; \mathrm{ACh}=25 \mu \mathrm{M}$, point mutant versus wild type, $p<0.0005 ; \mathrm{ACh}=25 \mu \mathrm{M}$, charge mutant versus wild type, $p<0.005$; $\mathrm{ACh}=25 \mu \mathrm{M}$, point mutant versus charge mutant, $p<0.025 ; \mathrm{ACh}=$ $10 \mu \mathrm{M}$, point mutant versus wild type, $p<0.005$ (see Table 2 for more details).

was no substantial difference between the two types of channels (wild type $=52.3 \pm 0.5 \mathrm{pS}, n=4 ;$ mutant $=56.7 \pm 0.3 \mathrm{pS}, n$ $=3$ ).

\section{Discussion}

We have studied the role of phosphorylation in the regulation of desensitization and expression of the AChR in Xenopus oocytes using site-specific mutagenesis techniques. When expressed in oocytes, the AChR is phosphorylated exclusively at sites within the intracellular loops of the $\delta$ and $\gamma$ subunits that have previously been shown to be recognized by PKA. These sites contain the consensus sequence for PKA phosphorylation: RRXSX, where X is any amino acid (Zetterqvist et al., 1990). Our results demonstrate that two serines at each site are phosphorylated in Xenopus oocytes: serines 353 and 354 on the $\gamma$ subunit and serines 361 and 362 on the $\delta$ subunit. Both serines on the $\gamma$ subunit may be phosphorylated by PKA since the sequence RRRSSF (residues 350-355) can be read as two overlapping PKA sites. In contrast, the site on the $\delta$ subunit is RRSSSV (residues 358-363). Phosphorylation at serine 361 on the $\delta$ subunit is consistent with the PKA motif; however, phosphorylation at serine 362 introduces an additional amino acid residue between the two arginine residues and the phosphorylated serine residue. Our results indicate that this serine can also be a target for PKA phosphorylation. Serine 360 on the $\delta$ subunit is not

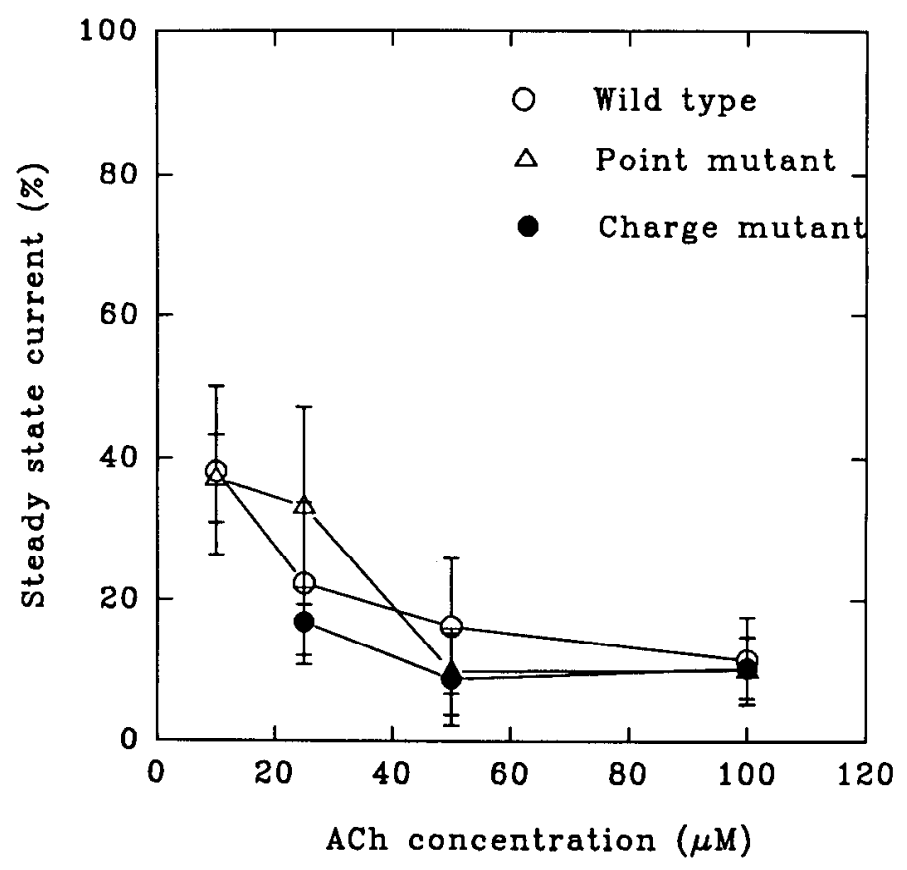

Figure 7. Steady state current versus ACh concentration. Steady state current was determined by subtracting the desensitized state from the peak current. Values are mean \pm SD. Patches were held at $-70 \mathrm{mV}$ (see Table 2 for more details).

phosphorylated. Previous studies have identified only serines 353 and 361 on the $\gamma$ and $\delta$ subunits, respectively, as the sites phosphorylated in vitro on the purified AChR by the purified catalytic subunit of cAMP-dependent protein kinase (Yee and Huganir, 1987). The difference between these results may be due to differences in in vitro versus in vivo phosphorylation of the AChR. Alternatively, serine 353 on the $\gamma$ subunit and serine 361 on the $\delta$ subunit may be the major sites phosphorylated by PKA in vivo and the phosphorylation of serine 354 on the $\gamma$ subunit and serine 362 on the $\delta$ subunit may occur only when serines 353 and 362 are mutated to alanine residues. However, it is interesting to note that Schrocder et al. $(1990,1991)$ have reported that both serines 361 and 362 in the $\delta$ subunit are phosphorylated in the $\mathrm{AChR}$ isolated from Torpedo electric organ.

We have attempted to modulate the level of phosphorylation of the AChR expressed in oocytes by increasing the intracellular levels of CAMP and by injection of the mRNA encoding the catalytic subunit of PKA. Neither protocol had a significant effect on $A C h R$ phosphorylation, suggesting that the average stoichiometry of phosphorylation on the AChR when expressed in oocytes is high due to the endogenous levels of PKA activity. This is in agreement with Belle et al. (1979), who found that an increase in intracellular cAMP does not change the banding pattern of phosphorylated proteins in Xenopus oocytes. It is also consistent with the observations that the catalytic subunit was mostly disassociated in prophase-arrested oocytes (Maller and Krebs, 1977; Huchon et al., 1981; Cicirelli et al., 1988). All of the phosphorylation of the AChR $\gamma$ and $\delta$ subunits in oocytes appears to be due to PKA activity since phosphorylation of purified Torpedo AChR by oocyte extracts can be completely inhibited by the addition of the PKA-specific inhibitor peptide $\mathrm{IP}_{20}$-amide. This data suggests that channel proteins expressed in Xenopus oocytes may be constitutively highly phosphorylated 
on intracellular PKA sites, complicating studies of ion channel modulation in oocytes.

Several recent studies have suggested that increased receptor phosphorylation is correlated with increased surface expression of receptor. Forskolin and other agents that increase intracellular cAMP have been found to increase the level of surface AChR in mouse fibroblasts containing stably integrated Torpedo AChR subunits (Green et al., 1991 a; Ross et al., 1991). Increased PKA phosphorylation of the $\gamma$ subunit, leading to longer subunit lifetimes and increased efficiency of subunit assembly, has been suggested to mediate this effect (Green et al., 1991b). We have noted no consistent decrease in receptor expression with mutant $\gamma$ and $\delta$ subunits in which phosphorylation of the AChR has been eliminated. This result demonstrates that although PKA phosphorylation may regulate expression, it is not required for ACh R expression or function.

To examine the functional effects of phosphorylation, we studied ion channel properties of the wild-type and mutant AChRs using patch-clamp techniques. The rcsults of this study demonstrate the significance of phosphorylation in desensitization of the ACh receptor channel. Results of our experiments have shown that desensitization of the AChR channels proceed with time constants of 100-200 $\mathrm{msec}$ at higher concentrations of ACh and 500-800 msec at lower concentrations. The desensitization rates of mutant receptors in which the phosphorylated serine residues on the $\gamma$ and $\delta$ subunits were mutated to alanine residues, and thus lacked all phosphorylation sites, were slower than wild-type phosphorylated receptors at all ACh concentrations tested. Moreover, mutation of the phosphorylated serine residues to glutamate residues appears to partially mimic phosphorylation and produced receptors that desensitized with $\mathrm{ki}$ netics similar to the wild-type phosphorylated receptor. These findings suggest that phosphorylation of the $\mathrm{AChR}$ regulates its rate of desensitization and confirm earlier studies using biochemical and patch-clamp techniques (Albuquerque, 1986; $\mathrm{Hu}-$ ganir et al., 1986; Middleton et al., 1986, 1988; Mulle et al., 1988).

Our previous studies using quench-flow and stop-flow channel kinetic techniques demonstrated that cAMP-dependent phosphorylation of the purified and reconstituted AChR regulated its rate of desensitization (Huganir et al., 1986). The observed effect of phosphorylation in these previous experiments, however, was more dramatic and was dependent on the concentration of ACh. At $100 \mu \mathrm{M}$ ACh phosphorylation increased desensitization twofold, while at $10 \mu \mathrm{M}$ ACh phosphorylation increased desensitization eightfold. It is not clear why we observed only an approximately twofold effect, even at $10 \mu \mathrm{M} \mathrm{ACh}$, in the oocytes. However, the purified nicotinic receptor contains high levels of tyrosine phosphorylation, and it is possible that tyrosine phosphorylation of the AChR modulates the sensitivity of the AChR to PKA modulation. This type of interdependence between phosphorylation sites in the modulation of ion channels has recently been reported for the voltage-dependent $\mathrm{Na}^{+}$channel (Li et al., 1992) and cation channels in leech neurons (Catarsi and Drapeau, 1993). We have not been able to induce tyrosine phosphorylation of the $\mathrm{AChR}$ expressed in oocytes to test this hypothesis.

It is also nol clear why PKA modulation of AChR desensitization has been observed in some systems and not in others. One problem is that desensitization is a rapid process with time constants in the $100 \mathrm{msec}$ range and requires rapid perfusion techniques to accurately measure; therefore, many laboratories do not accurately determine the kinetics of desensitization. In addition, in both muscle cells and in oocytes the basal phosphorylation appcars to be constitutively high. Therefore, treatment of cells or patches with cAMP analogs or purified kinases may not regulate the state phosphorylation of the AChR.

The physiological relevance of desensitization of the nicotinic $\mathrm{ACh}$ receptor at the neuromuscular junction is not clear, since the termination of the synaptic response by the breakdown of $\mathrm{ACh}$ by acetylcholinesterase is much more rapid than desensitization. Thus, the physiological role of the modulation of desensitization of the receptor by phosphorylation has been elusive. However, desensitization and phosphorylation of ligandgated ion channels are well conserved and ubiquitous mechanisms of regulation of receptor function. All ligand-gated ion channels desensitize to agonist and recent studies have shown that the desensitization of GABA receptors is regulated by cAMPdependent protein phosphorylation (Moss et al., 1992). It is possible that desensitization may play different roles at different synapses. At some synapses transmission may be terminated by desensitization (Trussel et al., 1989, 1993). In addition, desensitization of receptors may play a role in modulating synaptic transmission during high-frequency firing of the presynaptic neuron or when resting levels of neurotransmitters in the synaptic cleft produce significant levels of steady state desensitization. Thus, regulation of desensitization by protein phosphorylation may play a important role in regulation of synaptic transmission.

\section{References}

Albuquerque EX, Deshpande SS, Arcava Y, Alkondon M, Daly JW (1986) A possible involvement of cyclic AMP in the expression of desensitization of the nicotinic acetylcholine receptor: a study with forskolin and its analogs. FEBS Lett 199:113-120.

Bellé R, Boyer J, Oxon R (1979) Endogenous phosphorylated proteins during maturation of Xenopus laevis oocytes. Gamete Res 2:137-145.

Bufler J, Franke Ch, Witzemann V, Ruppersberg JP, Merlitze S, Dudel J (1993) Desensitization of embryonic nicotinic acetylcholine receptors expressed in Xenopus oocytes. Neurosci Lett 152:77-80.

Cachelin AB, Colquhoun (1989) Desensitization of the acetylcholine receptor of frog end-plates measured in a vaseline-gap voltage clamp. J Physiol (Lond) 41 5:159-188.

Catarsi S, Drapeau P (1993) Tyrosine kinase-dependent selection of transmitter responses induced by neuronal contact. Nature 363:353355.

Cheng HC, Kemp BE, Pearson RB, Smith AJ, Misconi L, VanPatten SM, Walsh DA (1986) A potent synthetic peptide inhibitor of the cAMP-dependent protein kinase. J Biol Chem 261:989-992.

Cicirelli MF, Pelech SL, Krebs EG (1988) Activation of multiple protein kinases during the burst in protein phosphorylation that precedes the first meiotic cell division in Xenopus oocytes. J Biol Chem 263: 2009-2019.

Dilger JP, Brett RS (1990) Direct measurement of the concentrationand time-dependent open probability of the nicotinic acetylcholine receptor channel. Biophys J 57:723-731.

Dilger JP, Liu T (1992) Desensitization of acetylcholine receptors in BC3H-1 cells. Pfluegers Arch 420:479-485.

Dumont JN (1972) Oogenesis in Xenopus laevis (Daudin). J Morphol 136:153-180.

Eppig JJ, Steckman ML (1976) Comparison of exogenous energy sources for in vitro maintenance of follicle cell-free Xenopus laevis oocytes. In Vitro 12:173-179.

Franke C, Hatt H, Dudel J (1991) Steep concentration dependence and fast desensitization of nicotinic channel currents elicited by acetylcholine pulses, studied in adult vertebrate muscle. Pfluegers Arch 417:509-516.

Galzi JL, Revah F, Bessis A, Changeux JP (1991) Functional architecture of the nicotinic acetylcholine receptor: from electric organ to brain. Annu Rev Pharmacol 31:37-72.

Green WN, Ross AF, Claudio T (1991a) cAMP stimulation of ace- 
tylcholine receptor expression is mediated through posttranslational mechanisms. Proc Natl Acad Sci USA 88:854-858.

Green WN, Ross AF, Claudiơ T (1991b) Acetylcholine receptor assembly is stimulated by phosphorylation of its gamma subunit. Neuron 7:659-666.

Hamill OP, Marty A, Neher E, Sakmann B, Sigworth FJ (1981) Improved patch-clamp techniques for high-resolution current recording from cells and cell free membrane patches. Pfluegers Arch 391:85100.

Huchon D, Ozon R, Fischer EH, Demaille JG (1981) The pure inhibitor of cAMP-dependent protein kinase initiates Xenopus laevis meiotic maturation. Mol Cell Endocrinol 22:211-222.

Huganir RL, Greengard P (1983) cAMP-dependent protein kinase phosphorylates the nicotinic acetylcholine receptor. Proc Natl Acad Sci USA 80:1130-1134.

Huganir RL, Greengard P (1987) Regulation of receptor function by protein phosphorylation. Trends Pharmacol Sci 8:472-477.

Huganir RL, Racker E (1982) Properties of proteoliposomes reconstituted with acetylcholine receptor from Torpedo californica. J Biol Chem 257:9372-9378.

Huganir RL, Delcour AH, Greengard P, Hess GP (1986) Phosphorylation of the nicotinic acetylcholine receptor regulates its rate of desensitization. Nature 321:774-776.

Kemp B (1976) Synthetic hexapeptide substrates and inhibitors of $3^{\prime}$ : 5'-cyclic AMP-dependent protein kinase. Fed Proc 35:1384.

Kunkel TA, Roberts JD, Zakaur RA (1987) Rapid and efficient sitespecific mutagenesis without phenotypic selection. Methods Enzymol 154:367-382.

Laemmli UK (1970) Cleavage of structural proteins during the assembly of the head of bacteriophage T4. Nature 227:680-685.

Li M, West JW, Scheuer T, Catterall WA (1992) Convergent regulation of brain sodium channels by cAMP-dependent protein kinase and protein kinase C. Soc Neurosci Abstr 18:1133.

Maconochie DJ, Knight DE (1989) A method for making solution changes in the submillisecond range at the tip of a patch pipette. Pfluegers Arch 414:589-596.

Maller JL, Krebs EG (1977) Progesterone-stimulated meiotic cell division in Xenopus oocytes. J Biol Chem 252:1712-1718.

Methfessel C, Witzemann V, Takahashi T, Mishina M, Numa S, Sakmann B (1986) Patch clamp measurements on Xenopus laevis oocytes: currents through endogenous channels and implanted acetylcholine receptor and sodium channels. Pfluegers Arch 407:577-588.

Middleton P, Jaramillo F, Scheutze SM (1986) Forskolin increases the rate of acetylcholine receptor desensitization at rat soleus endplates. Proc Natl Acad Sci USA 83:4967-4971.

Middleton P, Rubin LL, Schuetze SM (1988) Modulation of acetyl- choline receptor desensitization in rat myotubes. J Neurosci 8:34053412.

Miles K, Anthony DT, Rubin LL, Greengard P, Huganir RL (1987) Regulation of nicotinic acetylcholine receptor phosphorylation in rat myotubes by forskolin and cAMP. Proc Natl Acad Sci USA 84:65916595.

Miles K, Greengard P, Huganir RL (1989) Calcitonin gene-related peptide regulates phosphorylation of the nicotinic acetylcholine receptor in rat myotubes. Neuron 2:1517-1524.

Moss SJ, Smart TG, Blackstone CD, Huganir RL (1992) Functional modulation of $\mathrm{GABA}_{\mathrm{A}}$ receptors by cAMP-dependent protein phosphorylation. Science 257:661-665.

Mulle C, Benoit P, Pinset C, Roa M, Changeux JP (1988) Calcitonin gene-related peptide enhances the rate of desensitization of the nicotinic acetylcholine receptor in cultured mouse muscle cells. Proc Natl Acad Sci USA 85:5728-5732.

Naranjo D, Brehm P (1993) Modal shifts in acetylcholine receptor channel gating confer subunit-dependent desensitization. Science 260: 1811-1814.

Ross AF, Green WN, Hartman DS, Claudio T (1991) Efficiency of acetylcholine receptor subunit assembly and its regulation by cAMP. J Cell Biol 113:623-636.

Schroeder W, Covey T, Hucho F (1990) Identification of phosphopeptides by mass spectrometry. FEBS Lett 273:31-35.

Schroeder W, Meyer HE, Buchner K, Bayer H, Hucho F (1991) Phosphorylation sites of the nicotinic acetylcholine receptor. Biochemistry 30:3583-3588.

Siara J, Ruppersberg JP, Rüdel R (1990) Human nicotinic acetylcholine receptor: the influence of second messengers on activation and desensitization. Pfluegers Arch 415:701-706.

Trussell LO, Fisch bach GD (1989) Glutamate receptor desensitization and its role in synaptic transmission. Neuron 3:209-218.

Trussell LO, Zhang S, Raman IR (1993) Desensitization of AMPA receptors upon multiquantal neurotransmitter release. Neuron 10: 1185-1196.

Wagoner PK, Pallotta BS (1988) Modulation of acetylcholine receptor desensitization by forskolin is independent of cAMP. Science 240: 1655-1657.

White MM (1988) Forskolin alters acetylcholine receptor gating by a mechanism independent of adenylate cyclase activation. Mol Pharmacol 34:427-430.

Yee GH, Huganir RL (1987) Determination of the sites of cAMPdependent phosphorylation on the nicotinic acetylcholine receptor. J Biol Chem 262:16748-16753.

Zetterqvist O, Ragnarson U, Engstrom L (1990) In: Peptides and protein phosphorylation (Kemp BE, ed), pp 171-183. 